
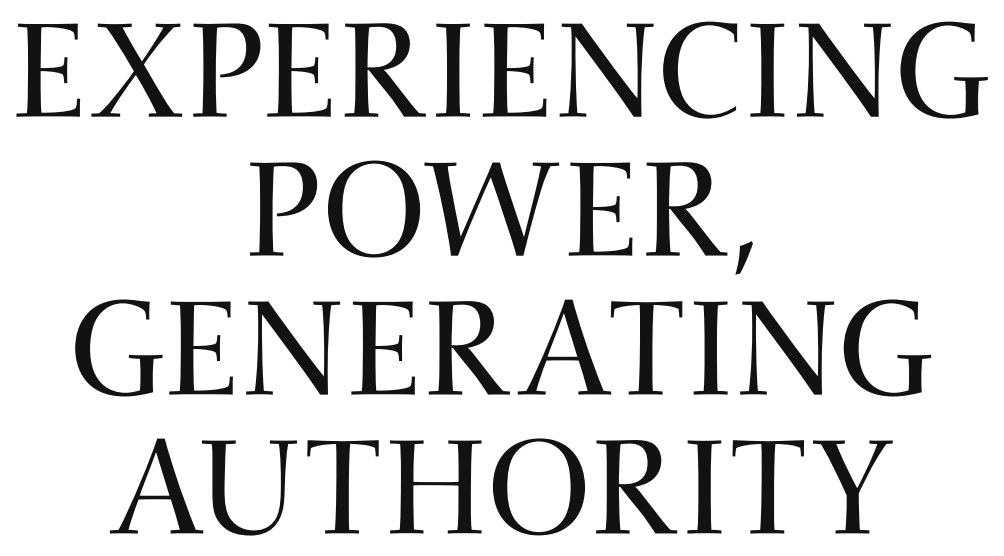

Cosmos, Politics, and the Ideology of Kingship in Ancient Egypt and Mesopotamia

\author{
EDITED BY \\ Jane A. Hill, Philip Jones, and \\ Antonio J. Morales
}

University of Pennsylvania Museum of Archaeology and Anthropology Philadelphia 
Library of Congress Cataloging-in-Publication Data

(C) 2013 by the University of Pennsylvania Museum of Archaeology and Anthropology Philadelphia, PA

All rights reserved. Published 2013

Published for the University of Pennsylvania Museum of Archaeology and Anthropology by the University of Pennsylvania Press.

Printed in the United States of America on acid-free paper. 


\section{Propaganda and Performance at the Dawn of the State}

\section{ELLEN F. MORRIS}

ccording to pharaonic ideology, the maintenance of cosmic, political,
and natural order was unthinkable without the king, who served as the crucial lynchpin that held together not only Upper and Lower Egypt, but also the disparate worlds of gods and men. Because of his efforts, society functioned smoothly and the Nile floods brought forth abundance. This ideology, held as gospel for millennia, was concocted. The king had no supernatural power to influence the Nile's flood and the institution of divine kingship was made to be able to function with only a child or a senile old man at its helm. This chapter focuses on five foundational tenets of pharaonic ideology, observable in the earliest monuments of protodynastic kings, and examines how these tenets were transformed into accepted truths via the power of repeated theatrical performance. Careful choreography and stagecraft drew upon scent, pose, metaphor, abject foils, and numerous other ploys to naturalize a political order that had nothing natural about it. Some of these tactics were abandoned after they had served their purpose or began to inspire negative backlash, while others survived to be drawn upon by Augustus and his successors.

By the end of an extended Nile Valley cruise, it is common for tourists to express the sentiment that they don't care if they never see another Egyptian temple. From Aswan to Alexandria, the traveler encounters innumerable representations of Pharaoh in the largely homogenous (mostly) New Kingdom and Ptolemaic temples they are ushered through. They see statues that may vary a bit in posture (seated versus standing, primarily) or 
size (some were particularly large!), and reliefs that may differ slightly in subject matter (the king may be smiting a group of foreigners or he may be standing on a chariot and shooting into a tangled mass of them. Likewise, he may be offering before a deity, embracing a deity, or performing a ritual in divine company). In essence, however, in the temples that the tourist has toured, two primary messages have been driven home ad nauseum. The king is the aggressive defender of his people, and the king is the only mortal who is on the same plane with the divinities and who may enter into relations of reciprocity and affection with them.

Egyptologists see nuances that travelers might not. Notions of kingship clearly fluctuated according to periods and personalities. The pyramids at Giza and the colossal statues of Amenhotep III and Rameses II, for example, occupy one end of the pendulum of royal deification and aggrandizement, while kings who reigned in and around Egypt's Intermediate Periods and purportedly authored pensive ruminations expressing vulnerability and even loneliness sit at the other. Further, some kings are known to us as specific personalities given their excitement at the prospect of viewing a pygmy (Pepy II), their unusually big ears (Senusret III: "the better to hear you with"), their propensity to boast about feats of physical prowess in unusual ways (Amenhotep II), or their love of horses (Piankh). It is the humanness and individuality of various rulers that breathes life into Egyptian history and provides the pleasure in studying it. Even the most casual of those weary tourists that daily board their planes homeward, however, have passively grasped the foundational tenets of pharaonic kingship — so assiduously did the Egyptians curate them over millennia. It is the purpose of this chapter to address the foundation, dissemination, and eventual naturalization of these tenets.

The notion that pharaoh was absolutely essential to the proper functioning of Egypt's religious, military, and administrative endeavors existed from its "conception in the egg" in protodynastic times to its slow death under the absentee pharaohs of the Roman period. As it was not uncommon for pharaohs to ascend the throne as "nestlings" or to rule despite crippling disease or extreme old age, this illusion was vulnerable to an easy unmasking. Clearly, the state could function perfectly well with only the pretence of an authority figure at its apex. Further, even in those rare periods when Egypt was politically fragmented, the sun continued to rise and set, and the Nile flooded its banks and fertilized the soil. The question is: how did a small, newly powerful group at the dawn of the state convince the recently 
conquered population of the Nile Valley that the unapproachable stranger king they promoted was vital to the welfare of the world? Moreover, how did the single office of kingship usurp and maintain a hold over all of the most highly valued sources of social power?

To answer these questions, I will utilize three pioneering articulations of royal ideology as a springboard for a discussion of propaganda and performance (or, perhaps better, propaganda in performance). These three monuments - the Narmer Palette and two impractically large maceheads, dedicated by King Narmer and King Scorpion to the god Horus of Hierakonpolis-are deservedly well known. Perhaps ironically, considering that they predate the Early Dynastic Period, they surpass any extant monuments of that time in their ability to efficiently communicate the various roles of the king at this period and the belief systems that surrounded him. While these objects may have been meant for the eyes of the god, the scenes portrayed upon them, I argue, were dramatic rituals that conveyed in their performance five foundational ideological precepts. These messages, writ large on these three royal monuments, were simultaneously disseminated by other means, and evidently so inculcated the Egyptian worldview that they together constituted a set of truths that remained essentially unquestioned for millennia. Although there were plenty of revolts in ancient Egypt's history, we know of no revolutions. According to all available records, rebels within Egypt sought to be the king rather than to abolish kingship as an institution. Thus the fatigue of the modern tourist is a direct legacy of the success of Scorpion, Narmer, and the individuals who helped these kings and their successors in forging a new dominant paradigm.

\section{THE MEDIUM: GIFTS TO BE GRASPED BY THE GODS}

Before addressing the key visual messages carved into the three votive objects, it is important to provide background on the monuments and their makers. King Scorpion, who dedicated one of the large maceheads under discussion (see Fig. 1.1) to a temple that he may well have founded, is known primarily by virtue of this monument, though the scorpions that appear on many other items in the Main Deposit at Hierakonpolis and in other contemporary contexts may betray his sponsorship. Although it is not certain where, nor even when precisely, he ruled, the similarity in shape and style of his macehead to the other votive macehead under discussion (see Fig. 1.2) render it 


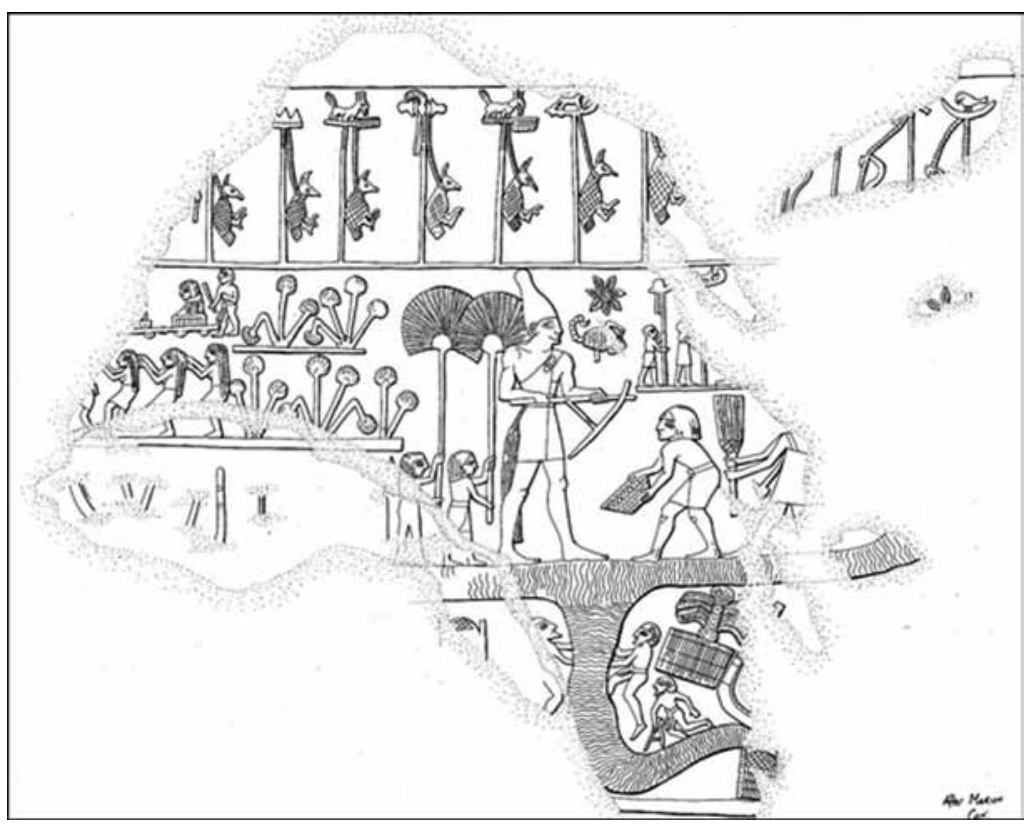

1.1. The Scorpion macehead Oxford, Ashmolean Museum E.3632 (after A.J. Spencer 1993:56, fig. 36. Drawing: Marion Cox).

extremely likely that he ruled just prior to Narmer, at the very cusp of the First Dynasty. Narmer's macehead is well known and his palette (see Fig. 1.3) is one of Egypt's most emblematic works of art. Narmer is also memorialized on a label discovered at Abydos (see Fig. 1.4), an ivory cylinder seal also from the Main Deposit (see Fig. 1.5), and a variety of other artifacts, including a

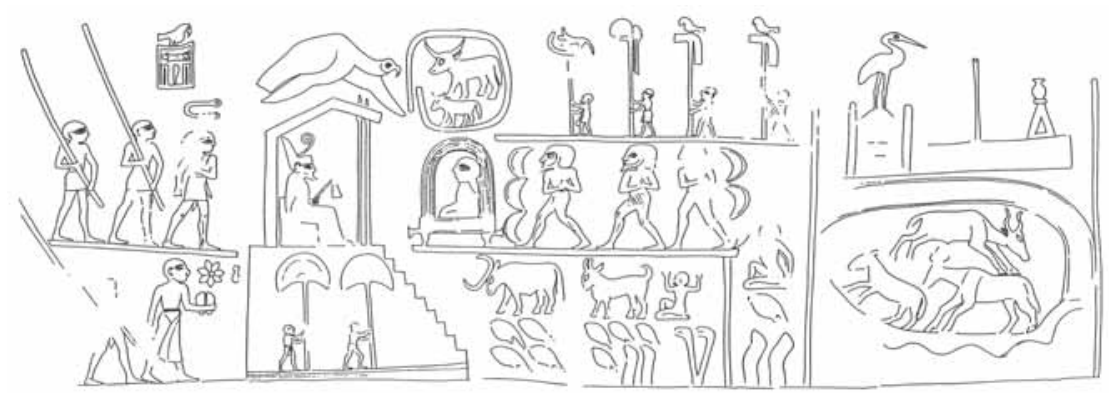

1.2. The Narmer macehead, Ashmolean E. 3631 (after Friedman 1992:31, fig. 12). 
great many storage jar fragments discovered throughout Egypt and southern Canaan. His double grave in the royal cemetery at Abydos practically abuts his successor's sprawling mortuary monument, and there is much debate as to whether he or Hor-Aha should be equated with King Menes, who later Egyptians viewed as the first king to inherit the throne of Horus (Brunner 1982).

The two maceheads and the palette under discussion were discovered in a cache of occasionally precious and always enigmatic Naqada III and Early Dynastic artifacts deposited together under the floors of the temple of Horus, Egypt's archetypal legitimate god-king (Quibell 1900; Quibell and Green 1902; Adams 1995:54-75). Thus their findspot provides a rare window into the intended audience of these items. Like the foundation cylinders of later Mesopotamian kings, the messages written upon these votives were meant for an unearthly audience and for those Egyptians privileged enough to gain access to sacred ground. While such items may have been at times displayed to the kings' subjects (such as in religious processionals) or have been published on other media, there is no way of ascer-

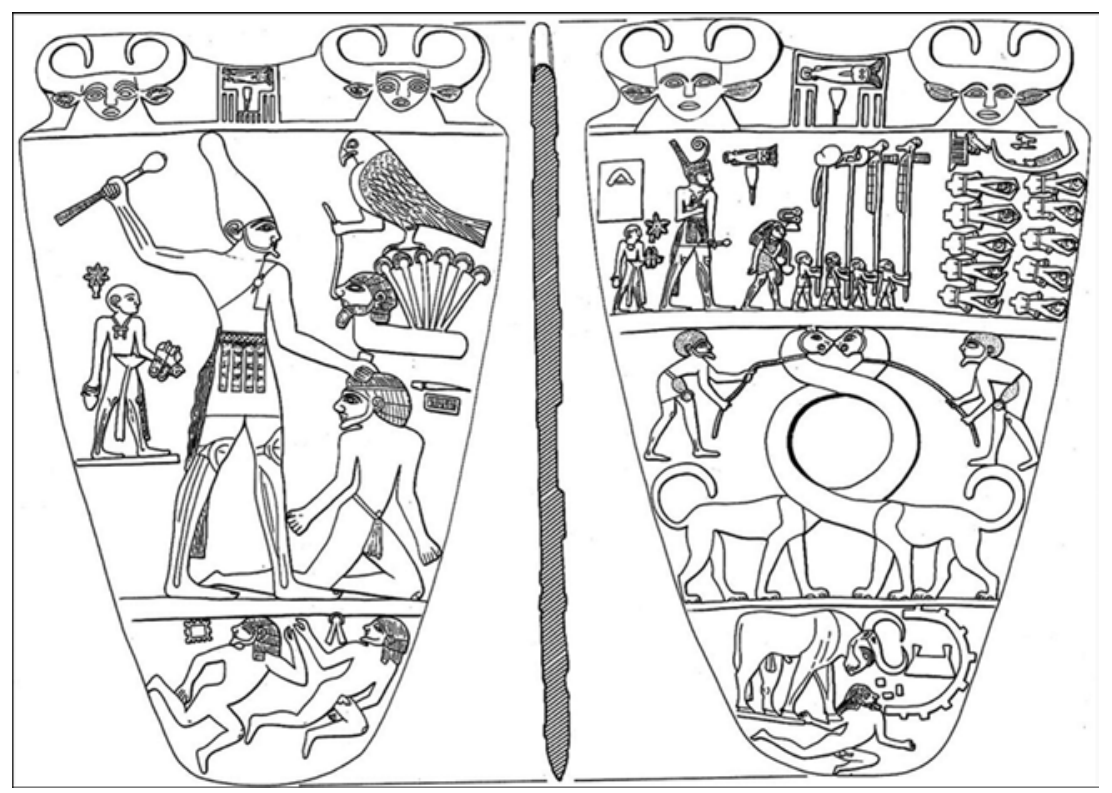

1.3. The Narmer Palette, Cairo J.E. 14716, C.G. 32169 (after Kemp 1991:42, fig. 12). 
taining this, and John Baines (1994:78) is probably correct in questioning their traditional interpretation as state propaganda - at least in the sense that this term is usually employed.

That these items were explicitly fashioned as gifts for a god is also driven home by their extraordinary size, for their scale is not appropriate to humans. If the roughly contemporary colossi of Min discovered at Koptos may be taken as a rough guide for the envisioned size of at least some deities (i.e., in excess of 4 meters high), however, these presents were indeed perfectly scaled for a divine being (see Kemp 2000 and Fig. 1.6). The impractically large flint knives also discovered in the Main Deposit assuredly fell into this category (Quibell and Green 1902:6, pl. 3), and it is likely that the tradition of providing divinized entities with gifts appropriate to their stature can be traced at least as far back as the votive deposits of massive flint arrowheads discovered in association with an early Naqada II pillared structure in Hierakonpolis' earliest elite cemetery. ${ }^{1}$ The god Seth, the

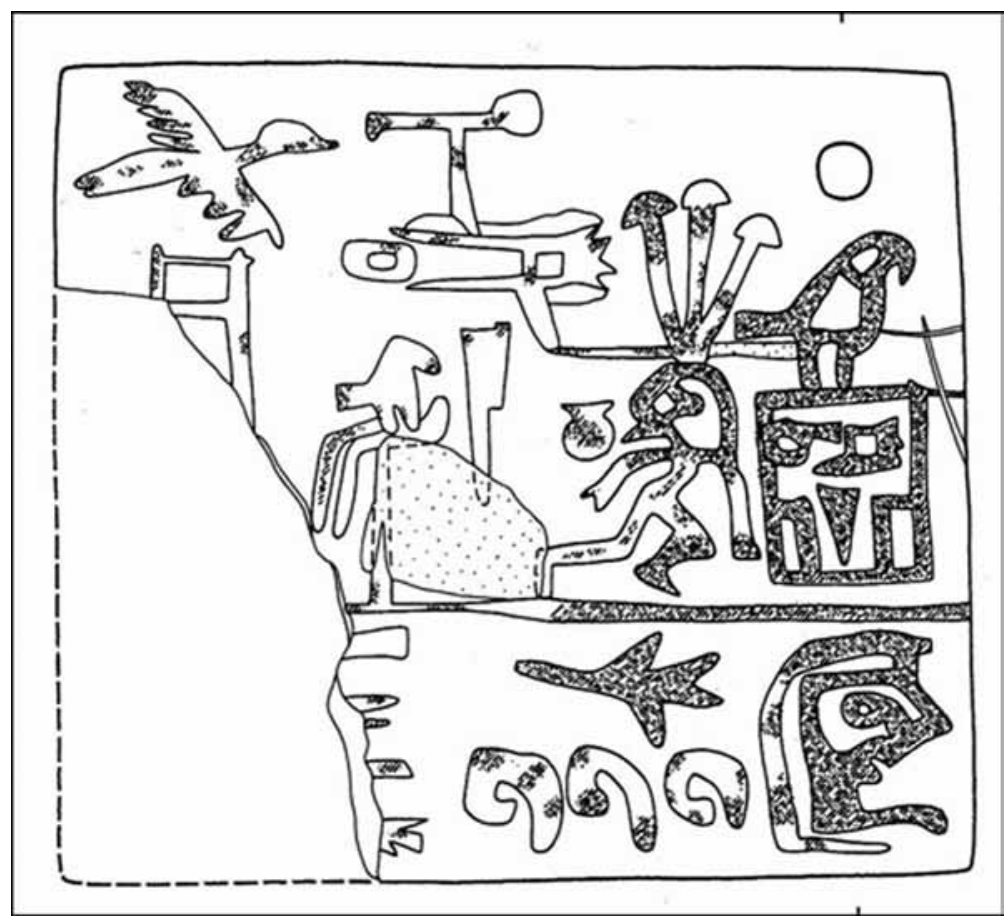

1.4. Narmer's label from Abydos. Drawing: author. 
strongest of all gods, was known to have wielded a weapon weighing many thousands of pounds in his nightly combat against the forces of darkness (Te Velde 2001:269). For the mere mortals who glimpsed these votive maceheads that they had not the strength to wield - not to mention the gigantic palette presumably made to fit comfortably into the palm of a god's handthe effect of their own miniaturization with respect to the cosmic world must have been vertiginous and humbling.

Votive gifts in Egypt as elsewhere were typically offered either as thanks for divine favors or in pious solicitation of them, and in many cases they were fashioned so as to appeal to aspects of a deity's character and/or to the type of favor requested (a phallus for fertility, etc.). The gift of the maceheads, then, may well have been a token of thanks for the victories whose aftermaths appear to be engraved upon them. On the Narmer Palette, which explicitly commemorates a victory, the king raises high his own mace to dispatch his prize prisoner. The word for mace $(\underline{h d})$ was a homophone of the word "white" or "bright," which was used to designate the white Upper Egyptian crown $(h \underline{d} t)$ that Narmer wore for this act of smiting and also the radiant whiteness that purportedly shone from the walls of the first capital at Memphis (Erman and Grapow 1929:206-11). This weapon, then, was entangled on multiple levels with concepts of kingship and served as a particularly fitting gift to be bestowed upon Egypt's celestial hawk-king by his earthly avatar. Certainly, the fact that pharaohs continued to grasp the mace in smiting scenes and statuary thousands of years after the weapon had become obsolete in contemporary warfare is a testament to the power of these early images, so imbued with symbolism, to endure.

\section{THE MESSAGE: THE KING DOES NOT BELONG TO THE ORDINARY REALM OF HUMANKIND}

Conventions of comparative size and physical placement on the two maceheads and on the palette drive home the point that the king's status was far divorced from that of even the highest officials of his kingdom (assuming that the ubiquitous $t$-official and Narmer's sandal-bearer fall into this category). Thus, when standing, no other individuals reach as high as the king's waistband, due either to their artificial shrinkage or to their crouched and submissive stance. When he sits enthroned, as the king does in the Narmer macehead, it is atop a nine-stepped platform - perhaps symbolic of the nine 
gods of the ennead or decorated with the nine traditional enemies of Egypt that he would crush underfoot upon mounting the platform. Whatever his posture or placement, the message is unambiguous: the king towers above humanity. The same rules that bind flesh and blood do not apply to him.

Such artistic - and no doubt performative-chicanery in the service of visually communicating this ideology was adopted by virtually all subsequent kings. To this end, later pharaohs appeared before their subjects in elevated windows of appearance. They sailed in royal barques or rode chariots, while others walked, rowed, or ran beside them. Kings traveled also in raised palanquins, and when they held audience, even the greatest magnates of their kingdom laid flat and kissed the ground. The inscriptions of the Fifth Dynasty grandees Ptahshepses (the high priest of Ptah and the husband of a princess) and Washptah (a vizier and chief architect) go further in informing us that the very highest honor, bestowed separately upon both of these two great men and deemed worthy of memorializing for eternity in their mortuary inscriptions, was that the king had commanded them to kiss his foot rather than the earth in front of him (Urk. I:41,15; 53,23; Strudwick 2005:304-5, 318-20).

Indeed, the manner in which the literary character of Sinuhe narrates his audience with Senusret I suggests that such elaborate self-abasement in the royal presence was not an artifact solely of the Old Kingdom. "I found his Majesty on the great throne in the portal of electrum. Then I was stretched out prostrate, unconscious of myself in front of him, while this God was addressing me amicably. I was like a man seized in the dusk, my soul had perished, my limbs failed, my heart was not in my body. I did not know life from death" (Parkinson 1997:40). Lest it be thought that such paroxysms of dread awe in the royal presence were purely fictional, Senusret I's own vizier, a man named Mentuhotep, bore among his most vaunted epithets two that boasted of his privileged position with respect to the physical person of the king, namely "master of every wardrobe of Horus" and he "who approaches the limbs of the king" (Breasted 1988a:256, 257). Clearly the opportunity to touch the royal person or to touch royal things (such as the king's sandals!) was reserved for a very tightly guarded inner circle. And even within this circle, unauthorized touching (such as the accidental contact made between a priest and "keeper of accoutrements" and the king's scepter) was potentially of the direst consequence (Urk. I:232,5-16; Strudwick 2005:305-6). 
In the Old Kingdom, the reigning king was termed not only a god

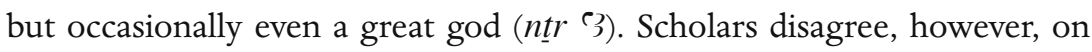
what the Egyptians actually meant by "god" (Was this term anticipatory of a transmutation that would only fully take place after death? Was it only the abstracted office of kingship that was divine? Or was the living king himself infused with a supernatural spirit?). For the earliest rulers especially, the extent of their divinity can only be guessed at, although the fact that in Khasekhemwy's fifteenth year a copper statue named High-isKhasekhemwy was "born" ( $m s t$ ) suggests that it may have received cult attention prior to the death of the king, as certain statues of Old Kingdom rulers did (Baines 1995b:132). In the New Kingdom, of course, Amenhotep III, Tutankhamun, and Rameses II likewise bolstered their own reputations as living gods by commissioning named statues of themselves that were invested with the individual agency to hear prayers in their stead (Wilkinson 2000:PS r.V.4; Baer 1960:264-72; Habachi 1969:40-52; Wildung 1977:1-30).

Judging from the imagery engraved on the votives dedicated by Scorpion and Narmer, the literal and figural elevation of these kings above humanity leant itself to the cultivation of a divine aura. Interestingly, in the theatrics of sacred kingship, scent may have also been employed to serve the same purpose. If the king to some extent could not help resembling a human being, he could at least smell like a god. A recurrent trope in narratives of encounters with the divine in Egypt held that gods exuded from their pores the fragrance of the finest incense (Hornung 1982:133-34). It may be no coincidence, then, that one of the earliest items subject to taxation at the dawn of the state was a commodity called the "fragrance of Horus." Scent certainly played an important role in the coronation rites, for it was believed that the incense that suffused the heir apparent during the ceremonies was in turn emitted from his own skin following their completion. In a dramatized pre-enactment of a Middle Kingdom coronation, the actor depicting the god Thoth commanded the god-to-be, just prior to crowning him king, "Take you the fragrance of the gods [censing], that which cleanses, which has come out of yourself” (Frankfort 1978:130-32).

At the death of the pharaoh, when the king's sacred nature lost any ambiguity whatsoever, scent also played an enormous role, for the king wished to affirm that his sweat was the sweat of Horus and that his odor was the odor of Horus (Faulkner 1969:PT 508). To this end, it seems, no expense was spared. In excavating the First Dynasty King Semerkhet's royal tomb, Flinders Petrie 
speculated that "hundredweights" of perfumed unguents must have been poured at the entrance of the sepulcher and observed that "the scent was so strong in cutting away this sand that it could be smelt over the entire tomb" (1989 [1900]:14). This description calls to mind the congealed tar of scented substances that had been poured so generously over Tutankhamun's corpse that his body stuck fast to the floor of his coffin three millennia after burial (Carter 1972:140-41). This fragrance of Horus-no doubt dispensed with extra urgency to mask the stench of death-seems to have been employed as "proof" of the king's divinity even in the state's earliest days.

The king's intimate association with the god Horus, whose scent he shared, is emphatic in Narmer's monuments. On his macehead, for instance, the serekh implies that the king is Horus-in-the-palace (as opposed, perhaps, to Horus-in-the-temple or Horus-in-the-sky), while on the palette, the king's crown and the falcon-head of Horus both graze the sky as the two subdue their foes in parallel. Likewise, on a royal cylinder seal (see Fig. 1.5), Horus extends the sign of life to Narmer's personified catfish, which was engaged in the act of dominating prisoners with a long cudgel. The king's essential relationship with his divine counterpart-whose spirit no doubt entered the king's body upon coronation-was also emphasized by Early Dynastic rulers in their names, either directly (such as Hor-Aha-Horus-thefighter) or obliquely (as one of the "two powers" that this god comprised together with his rival Seth) or simply by virtue of the name of the name itself (i.e., the Horus name, Anedjib's

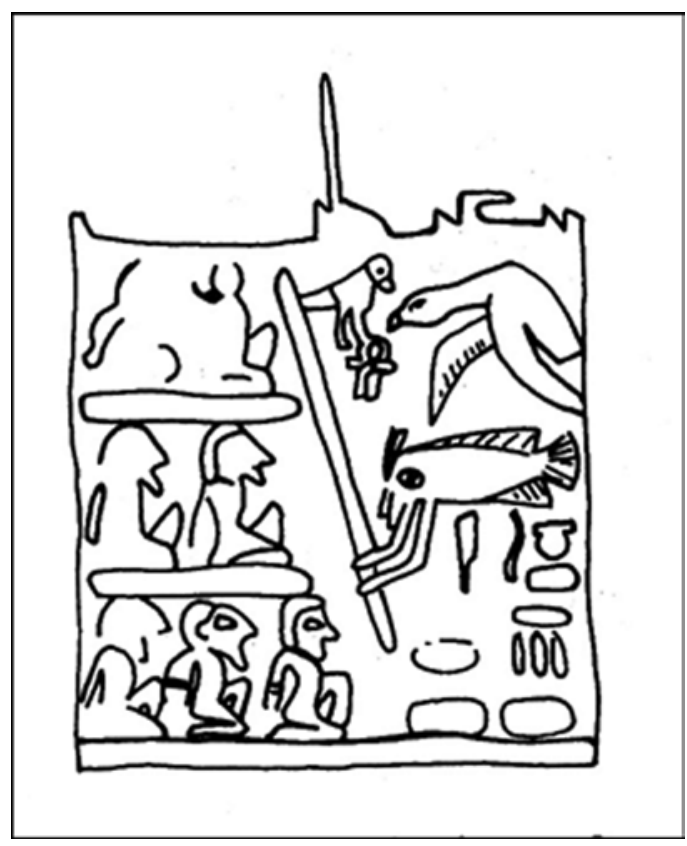

1.5. Narmer's ivory cylinder seal from Hierakonpolis. Drawing: author. 
Two Lords name, and perhaps the Golden Horus name as well). The designations of royal estates, also, regularly combined the name of the god Horus with an epithet (such as Horus-first-of-the-corporation-of-gods- $h r-t p i-h t-$ or Horus-star-of-the-corporation-of-gods—hr-sb3-htt) (Wilkinson 1999:119, 121-22).

If Horus played a starring role as the divine avatar of the king, Scorpion and Narmer also appear to have promoted the idea that their beings were infused with the bone-crushing power of the wild bull. At least two of the first powerful kings of Hierakonpolis, buried in Locality 6 in the early Naqada II period, had taken sacrificed bulls with them to the grave, perhaps in order to materialize the metaphor of the king as the "strong bull" of his people (Friedman 2004:138; Warman 2004). Later at Hierakonpolis, on the Narmer Palette, a bull acts as the proxy of the king in ramming down the fortifications of an enemy city and trampling its inhabitant(s), and a similar motif is found on the nearly contemporary bull palette. While in these cases the bull is only an artistic motif, perhaps intended to be viewed by an extremely limited audience, Early Dynastic kings associated themselves more publicly with the figure of the bull in two very important festivals. The first, the running of the sacred Apis-bull of Memphis, was one of the more frequent festivals in Early Dynastic Memphis and coincided on occasion with the "dawn/appearance" of the Lower (or Upper) Egyptian King (e.g., Wilkinson 2000:PS r.III.12; PS r.IV.10; CF4 r.M.1). On these occasions, the feared and ferocious bull would have been unleashed in the same set of ceremonies as the Memphite king appeared in state, visually impressing the equation of the two entities upon the audience. The other festival of note, the Heb Sed, occurred far less frequently, but it was the single most celebrated and fervently desired event of a king's rule. The festival was named after the ceremonial bull's tail that the king wore appended to his kilt, further attesting to the fundamental importance of the bull to the king's projected image.

Although the scenes depicted on Narmer's Palette and Scorpion's macehead cannot be definitively identified as components of the Heb Sed festival, it is notable that both kings are depicted on these monuments wearing a bull's tail. This deliberate fusion of man and animal as presented on public occasions may have been part and parcel of the cross-culturally common practice of "creating a stranger" that occurs when obvious mortals have to be remade into divine kings (Feeley-Harnik 1985:280-81). Indeed, such a 
method of enhancing the elevated otherness of the king would have been particularly effective in an Egyptian context judging from the fact that by the Early Dynastic Period gods often appeared, like the king, as human-animal hybrids. Other powerful animals, such as the lion-which destroyed cities in tandem with the scorpion and the falcon on the cities palette, devoured foes on the battlefield palette, and appeared amongst the buried retinue of king Hor-Aha-also captured the Early Dynastic imagination and served as enduring metaphors for pharaonic power. It was with the bull, however, that the spiritual synergy between king and beast was most profound.

Before segueing from this discussion of the supernatural aspects of archaic kingship, as gleaned from these three monuments and Early Dynastic public performances, I want to return to the subject of the mace, this time as grasped by Narmer on his way to view the decapitated corpses of his foes on the palette. Sometimes, as Freud would have it, a mace is just a mace. The shape of this particular mace, the manner in which the king grasped its stem firmly in his left hand, and the angle at which it protruded from his body, however, together effectively evoke the world-creating act of the cosmic deity. According to the Heliopolitan tradition, this original begetting via the act of masturbation was accomplished by Atum and his hand. The pose of the Koptos Collosi and the fact that one of these statues may have borne Narmer's name etched into its body (Williams 1988:36-37), however, suggest that the king was here visually alluding to his own partial syncretism with the ever-virile ithyphallic Min. While it is certainly a stretch to envision the king performing any such act before an audience, the poses of the king and the poses adopted by (statues of the) gods quite likely mirrored one another and influenced the way the king may have carried his mace or posed in public.

\section{THE MESSAGE: THE KING IS THE CHOSEN ONE OF THE GODS}

If it remains somewhat unclear whether the first kings of Egypt were thought of as deities incarnate, the protective hovering vulture goddess on the Narmer macehead, the multiple supportive appearances of Horus, the dual depictions of the celestial cow-goddess that flank the king's name on the palette, and the shrines engraved in the background of scenes on the two maceheads make it quite clear that the king was under the protection 
of the deities and in an intimate relationship with them. Indeed, until the mid-Second Millennium the king was as a rule the only mortal portrayed directly interacting with the gods, much less enfolded in their embrace, as many of the kings prior to that point were commonly depicted. On the subject of decorum (or perhaps actual taboo), however, it is also vital to note that mere mortals did not depict the king on their own religious or commemorative monuments until the end of Egypt's Middle Kingdom (Baines 1995a:10; Silverman 1995:83), suggesting perhaps that while both king and god belonged to the same category, the sacred nature of the cosmic deities was perhaps less contested or easily tarnished.

The reliance of the king upon the gods and the (no doubt) public demonstration of their support for him in the earliest days of Egyptian kingship is also demonstrated by the ubiquitous presence on these three monuments of the four sacred standards, which seem to have accompanied the king in ceremonial contexts. So far as it is possible to ascertain, this assemblage of sacred fetishes served a number of purposes: symbolizing aspects of the king's own divine nature, signaling his alliances with the deities depicted, and perhaps simultaneously celebrating particularly important terrestrial alliances. The two falcons, for example, are found as early as the cities palette engaged with other royal avatars in the process of hacking up walled polities, and here as well as on our monuments they may signify the Two Lords, Horus and Seth. These deities, according to royal doctrine, abandoned their internal quarrel and threw their combined weight and spiritual personae behind the king such that the royal queen held the title "[She]-who-seesHorus-and-Seth" (Te Velde 1967:68, 71). The dual falcons were also signifiers of the Coptite nome, however, and likely possessed a seat of worship there. If Koptos, in its key position as a powerful southern stronghold was instrumental in aiding the Abydene kings in their rise to supremacy, then the appearance of its city-symbol in royal processions should also be read as a special acknowledgment of the king's political supporters.

The other symbols that topped the remaining two standards also may be interpreted on multiple planes. The "cushion" was known as the king's nhn, most convincingly argued to be his placenta and thus the materialized presence of his spiritual twin (i.e., ka-Blackman 1915). The word $n h n$, however, is also a homonym of the Egyptian name for Hierakonpolis (Posener 1965:194-95) and may thus have constituted yet another avenue for the Abydene kings to emphasize their alliance with this highly influen- 
tial former rival. Finally, Wepwawet, the Opener-of-the-Ways, appears like Horus to have acted as the divine personification of the legitimate king, and the bulbous sled this god stood upon was said to have been the vehicle that transported the deceased king to the next world. The god's close ties to the ruler in death likely stemmed from the fact that Wepwawet was one of the earliest gods worshipped at Abydos. The role of this city as the victor in the struggle for control of Egypt is well known, and it may be that the god's presence here acted as a visual reference to the origin of the new kings. There is yet another (perhaps less likely) possibility, however. Wepwawet also functioned as the god of Asyut, a polity whose location between Middle and Upper Egypt lent it a pivotal role in the battles for the reunification of the country in the First Intermediate Period. If the region of Asyut played an analogous role in Egypt's first unification, the prestigious positioning of its standard in the royal entourage might have visually acknowledged the martial support the king had received from the city and its god (Frankfort 1978:92-93; DuQuesne 2005:390-97).

As we know from the regular reappearance of these standards at Sed festivals throughout Egyptian history, the group was collectively known as the šmsw $h r$ - the followers or attendants of Horus (or occasionally "The gods who follow Horus"). In later times the standards-perhaps because of their great antiquity - were closely identified with the divinized royal ancestors, who together endorsed the king's reign and granted him millions of years upon the throne. In the Turin Canon, for example, the šmsw hr designated the primordial kings that preceded Egypt's first mortal ruler and provided the direct link between his rule and that of the gods (Kaiser 1959; Baines 1995b:120, 125; Frankfort 1978:83-93). Together these standards served as a convenient cultic representation of the spirits of the seemingly innumerable individual kings who came before the reigning one and who bestowed upon him their blessing and divine aid. When first introduced in the protodynastic period, however, the standards almost certainly communicated to onlookers the message that the king's spiritual and political backers were the most powerful entities in the country.

Archaic year names and the official annals promote the idea that care for the gods, including perhaps divinized ancestors, was a supremely important royal responsibility. To this end the king proudly recorded-and indeed named whole years after-the birth of divine statues (e.g., those of Neith, Min, Anubis, Sed, and Mafdet). As we know from myriad later in- 


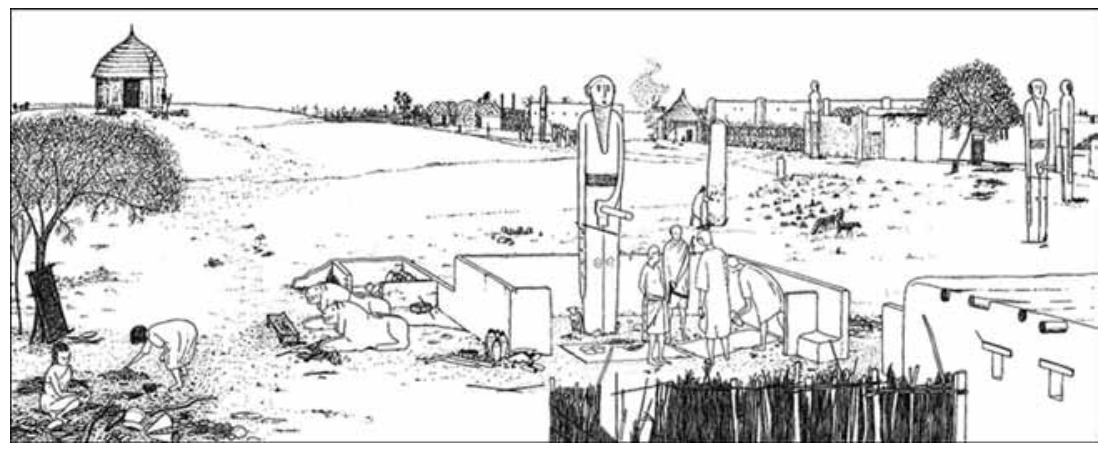

1.6. Reconstruction of Min colossi (after Kemp 2000:225, fig. 13).

scriptions, new statues were created as the direct result of royal edicts, and it is thus fascinating to note that in sponsoring the statues of deities, a king was to some extent identifying himself with the sole creator. According to the tradition preserved in the Memphite Theology, gods came into being via the conceived thought and spoken word of the supreme god (Ptah in Memphis). "He gave birth to the gods; he made the towns; he established the nomes; he placed the gods in their shrines; he settled their offerings; he established their shrines; he made their bodies according to their wishes. Thus the gods entered into their bodies, of every wood, every stone, every clay, everything that grows upon him in which they came to be. Thus were gathered to him all the gods and their kas, content, united with the Lord of the Two Lands" (Lichtheim 1975:55). Like the Early Dynastic king, Ptah resided in Memphis, bore royal titles, and created of his own initiative the bodies of the gods.

As part of his primordial cosmic duties, the typical Early Dynastic king also constructed new shrines and temples for the gods (e.g., the Thronesof-the-Gods, the Mouth-of-Horus, The Goddess-Abides, and the Throne-ofHorus-the-Harpooner). Moreover, he periodically officiated at their most important festivals (e.g., the Sokar Festival, the Adoring-Horus-of-the-Sky Festival, and the Sopdu Festival). The creation of statues and the founding or embellishment of various cults, especially those cults most easily adapted to the new royal ideology, assuredly entailed also the establishment of generous endowments, as are elaborated in the more detailed redactions of the Fifth Dynasty annals (e.g., Wilkinson 2000:PS v.II.2; PS v.III.1; PS v.IV.3). By participating in festivals that were no doubt promoted as essential to 
the country's welfare, the king created a stage for himself on which to be actively viewed by a substantial segment of his subjects performing vital spiritual work on their behalf. Likewise, by liberally bestowing wealth upon local power centers, the king may have attempted to purchase the loyalty of these regions and, especially, that of their most influential citizens.

If founding divine statues and temples were the deeds of the creator deity and of the creators of the Egyptian state, it is hardly surprising that rulers emulated these same deeds throughout pharaonic history. This exultant enumeration of Horemheb's accomplishments immediately after ascending the throne illustrates how direct royal involvement in cultic affairs could be. It takes little imagination to envision how the bestowal of such largess upon the cults of deities, not to mention cultic office upon king's men, worked to shore up political and spiritual support for all manner of pharaonic activity.

And lo, he set in order this land, organizing it after (the manner of) the time of Ra. He renewed the temples of the gods (from) the marshes of the Delta to Nubia. He fashioned all their images, distinguished above the original(s) and surpassing in beauty through what he did to them.... He sought out the precincts of the gods which were in ruins in this land and set them in order (even) as they were since the time of primal antiquity, and instituted for them regular offerings (on) every day, and every vessel of their fanes was fashioned in gold and silver. He equipped them with ordinary priests and lectors from the pick of the army, and opened up for them fields and herds equipped with all services, they rising up early to pay honor to Ra at the beginning of the morning every day: Do thou lengthen for us the kingship of thy son who does what pleaseth thy heart, Deserkheprure-setpenre, and mayst thou give him millions of jubilees [Heb Seds] and set his victories over all lands like Horus son of Isis, even as he propitiates thy heart in On and thy Ennead join thee. (Gardiner 1953:15-16)

The royal gifts lavished upon the gods were evidently impressive enough to prompt their priests to wake up early in the morning to pray earnestly for the king's continued well-being!

Horemheb's inscription is interesting to us for a second reason-namely that all his good works for the gods unabashedly functioned as currency in 
the classic royal barter whereby benefactions for the gods were provided in expectation of divine assistance in military matters. Indeed, this cosmic trade may have been as old as the institution of kingship itself, for the inclusion of the shrine of Buto $\left(\underline{D} b^{\ulcorner} w t\right)$ on the Narmer macehead in all likelihood indicated that a substantial portion of the prisoners and livestock arrayed before the king were to be donated to it. If so, we would have depicted on Narmer's two votive gifts the traditional royal cycle of reciprocity with the gods. On the palette, Horus aids (or animates) the king in battle, while on the macehead, the king returns to the gods a portion of the booty reaped from military victory as a token of appreciation for their support.

\section{THE MESSAGE: THE KING IS THE CRUSHER OF REBELS AND THE EXPANDER OF THE ORDERED STATE}

The Narmer Palette used to be read by scholars, and occasionally still is, as a symbolic narrative of Egypt's first unification. On the most visually striking side of the monument, Horus dominates a personified sign for the Northland $(t 3 \mathrm{mhw}$ ), while the divine falcon's earthly counterpart-The King of Upper Egypt (nswt) — raises high his mace to deal a deathly blow to (as was often thought) the former leader of Lower Egypt. On the opposite side of the palette, act accomplished, Narmer assumes his well-won title-King of Lower Egypt (bity) - and processes out to the battlefield to observe the neatly decapitated remains of the vanquished army.

As our understanding of the complexities of Egyptian prehistory has grown, however, this simplistic reading has been challenged. Upper Egyptian (and Upper Egyptian-style) pottery in early levels at Buto, tags discovered in the royal tomb $U_{-j}$ at Abydos, serekhs on far-flung storage jars, and various other lines of evidence have convinced archaeologists that Egypt was more-or-less culturally unified and economically dominated by the southern kings some generations prior to the reign of Narmer. The palette, then, it is argued, could not have memorialized Narmer's victory over a united Lower Egyptian kingdom. Rather it must have represented either a symbolic (re) statement of a fait accompli (Wengrow 2006:204) or perhaps, if it were a recording of a real event, it depicted a victory against outsiders, such as Canaanites, Libyans, or perhaps even Nubians (e.g., Kaplony 2002:472).

Given the visual reference to a dominated Northland, the most likely reading of the palette is that it commemorates the king's victory over the 
polity depicted as being broken and entered by the horns of the bull-king on the bottom register of the front side. Certainly, Dreyer's recent discovery at Abydos of a label bearing a year name, in which Narmer is shown grasping the papyrus plants growing out of the head of a bearded prisoner, supports the idea that the scenes on the palette were in fact linked to a specific event (see Fig. 4; Dreyer et al. 1996:139). While it is not necessary to see in the palette the commemoration of the defeat of the King of Lower Egypt, it is not unlikely that Narmer is indeed shown defeating $a$ Lower Egyptian kinglet, perhaps in a battle that was pivotal in establishing his uncontested control of the Delta. Certainly, the many "horizon A" serekhs discovered in the north during the Naqada III Period suggest that the idea of kingship was not restricted to the south, nor perhaps was it centralized in the north (Kaiser and Dreyer 1982: fig. 14; Köhler 2004:310). Seismic shifts in the power of the southern kings in and around Narmer's reign are clearly betrayed by the quantum leap in the geographic breadth and numerical saturation of his serekhs and also in the vast escalation in the size and opulence of those royal tombs erected following his reign. Thus it would appear likely that military ventures undertaken in his reign radically expanded his kingdom and that his successors were able to reap the substantial economic rewards of increased scale and security. Regardless, it is clear that the idea of the king as a fighter and a punisher (first witnessed perhaps in the Naqada II "Painted Tomb" at Hierakonpolis) was to emerge as a central tenet in the ideology of Early Dynastic kingship.

That Narmer and his successors were interested in projecting Egypt's influence not only over-but also beyond-the Nile Valley is demonstrated by the many serekhs bearing Narmer's name discovered in southern Canaan, often in conjunction with Egyptian enclaves (Braun 2002). Records from the reigns of Djer and Den, especially, demonstrate an interest not only in trading with but also in smiting easterners (Wilkinson 2000:PS r.III.2; CF1 r.II.5; CF5 r.L.2; Kaplony 2002:466). Nubia too seems to have incited avarice and aggression in Egypt's earliest pharaohs. The new kings prioritized the construction of the southern fortress at Elephantine, suggesting a clearly delineated vision of where Egypt's borders should officially be drawn. Further, victories such as those celebrated by Hor-Aha over Ta-Seti, and depicted in a graffito at Gebel Sheikh Suleiman by Scorpion and an unknown early ruler, resulted within a few generations in the total eradication of the rich and powerful kingdom at Qustul. With no rivals in the region, Early Dynastic 
and Early Old Kingdom rulers were left lords of a largely depopulated and eminently exploitable Lower Nubia (Wilkinson 1999:71-72, 178-81).

Egypt's third periphery was its western flank, and the word Tjehenu, which later signified this general area, appears already on the cities palette (albeit on the side depicting rows of animals, not the destruction of walled polities). This term presumably also designated the origin of the pinioned captives on Narmer's cylinder seal (see Fig. 1.5), and perhaps even (as witnessed by a sole " $n w$ " element) that of the papyrus-headed prisoner on Narmer's label (see Fig. 1.4). If the latter identification is correct, as Dreyer et al. (1996:139) believe, it may be that the term originally designated the land into which the inhabitants of the western Delta who resisted Upper Egyptian authority fled to escape the tentacles of the state. In such a scenario, the inhabitants of Tjehenu would have simultaneously constituted both foreigners and rebels. Whatever the identity of the decapitated soldiers on the Narmer Palette, it is perhaps safe to assume that their nakedness, the severance of their heads from their bodies, the orderly arrangement of their corpses, and their official viewing by Narmer and his entourage were all designed to showcase the humiliation and eternal damnation that awaited enemies of the Egyptian state. Royal smiting, which was the fate reserved for the most socially important individuals of a conquered people, was likely also a publicly staged event, replete with its own abasement and horror.

Like the scribes that would later compile execration texts, the artisans that crafted the palette and the two maceheads under discussion made sure to assert the universal supremacy of the Egyptian king against all possible enemies, both internal and external. Under Narmer's feet on the palette, defeated representatives of cities and of villages or perhaps nomadic tribes are represented (i.e., the two categories of those-who-inhabit-walled-towns and those-who-do-not). The two sets of penned animals on the king's macehead —one wild and the other domesticated—may also symbolically represent the emic dichotomy between ordered Egyptians and disordered foreigners. Lest this last suggestion seem perhaps a reach, on the Scorpion macehead two sets of dominated entities dangle by the neck from the standards of the king's supporters (whether these are interpreted as divine, terrestrial, or-most likely - both). On one half of the macehead (according to the most plausible reconstruction) the standards suspend bows, presumably the canonical "nine bows" that together stood for the entire assemblage of Egypt's enemies. On the better-preserved section of the macehead, how- 
ever, it is rekhyt-birds that swing by their necks. These lapwings, usually portrayed with wings pinioned behind their back and arms (!) raised in worship, designated the potentially rebellious classes within Egypt. Whether the papyrus plants that sprouted directly beneath the rekhyt on the Scorpion macehead were meant to signal their Lower Egyptian origin is unknown, but given the historical context, this is perhaps likely.

Explicit demonstrations of royal power directed toward an internal audience appear to have occurred periodically in the First Dynasty as the state worked to assert its authority. There is, for instance, the enigmatic record in the Palermo Stone of a ceremony in Djer's fourth year that was indicated by a lapwing with its throat severed-pictured in conjunction with the sign for "to cense" ( $k 3 p)$ and a seated figure (Wilkinson 2000:97-98, and fig. 1, PS r.II.6). Although the timing of this ceremony precludes an identification with the retainer sacrifices that took place at the time of the earliest dynastic burials, it is likely that the early state was here, as well, experimenting with how best to communicate the ideology that their new world order was worth dying for (Morris 2007). The scale of these funerary sacrifices reached an obscene pitch in the initial reigns of the First Dynasty, as hundreds of individuals were slain to bolster the otherworldly retinue of the dead king (compare Dickson, this volume, for discussion of a similar phenomenon in early Mesopotamia). Moreover, it is notable that within this impressive sample size of burials there is no osteological, archaeological, or inscriptional evidence to indicate that the victims were culled from the relatively expendable ranks of prisoners of war-quite the contrary. The bones, names, and depictions of those that escorted the deceased monarch to the afterlife are typically Egyptian.

With this in mind, it is of interest that three early First Dynasty labels from Saqqara and Abydos seem to depict the blood sacrifice of pinioned individuals in conjunction with mortuary imagery and that these bear the

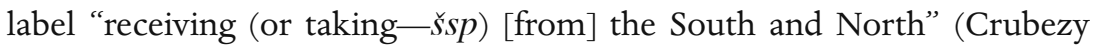
and Midant-Reynes 2000:30). It may be suggested, then, that sacrificial victims were consciously selected in state ceremony to serve as representatives from each of the Two Lands. Indeed, following from this observation, one wonders whether the statistically significant variance in the frequency and severity of porotic hyperstosis observed between the populations of retainers buried around the royal graves at Abydos and those that surrounded the valley temples may have been due to the fact that one group was tradition- 
ally harvested from the north and the other from the south (for the study on porotic hyperstosis, see Keita and Boyce 2006). The evident investment on the part of the King of Upper and Lower Egypt in emphasizing his own position as the lynchpin between the two lands will be addressed in the subsequent section.

The scale of the retainer sacrifices associated with royal funerals declined markedly as the First Dynasty wore on, presumably indicating that the state's point had been proven, or perhaps that the rulers began to realize that their message might be more receptively communicated if the killings abated. When instability again became an issue in Egypt during the waning years of Khasekhemwy's reign, however, massacres of Delta-dwellers were referenced in royal inscriptions yet again - interestingly, on statues recovered in the august company of the palette and maceheads in the Main Deposit at Hierakonpolis! While the smiting and wholesale slaughter of outsiders was to persist in Egyptian iconography right through and beyond the pharaonic period, the smiting of insiders-other Egyptians-largely disappeared from the artistic repertoire in favor of the more innocuous (and ubiquitous) image of rekhyt-birds, apparently content in their subdued state, worshipping the king. It is telling, however, that one of the rare exceptions to this rule-a scene of Nebhepetra Mentuhotep II smiting an Egyptian together with a Libyan, a Nubian, and an Easterner (Habachi 1963:39)—was fashioned by the very next individual to take a politically divided nation and forge it into the Kingdom of Upper and Lower Egypt.

\section{THE MESSAGE: IN THE KING'S PERSON UPPER AND LOWER EGYPT ARE UNIFIED}

On the two maceheads and the Narmer Palette the above message-assiduously perpetuated and elaborated upon by pharaohs over the ageswas already driven home. Narmer, of course, is seen in both an Upper and a Lower Egyptian crown on the palette, asserting his claimed sovereignty over both regions. Although he wears only a crown of Lower Egypt on the macehead, his dominance over the Two Lands was aptly signalled by the tutelary goddess of Upper Egypt, Nekhbet, who hovered in her aspect of vulture protectively just above his head. Finally, on the Scorpion macehead, the king is depicted in a crown of Upper Egypt, but Lower Egypt is visible in the multiple clumps of papyrus arrayed right behind him, and more 
than one scholar has suggested that this Upper Egyptian Scorpion would originally have faced a corresponding Lower Egyptian Scorpion on the portion of the macehead that is now all but entirely destroyed (see Baines 1995b:119).

By the reign of Djet, a short way into the First Dynasty, a new crown was developed that combined elements from the crowns of Upper and Lower Egypt to form together a single entity, known as the Two-Powers (sekhemty-Wilkinson 1999:73, 75, 196). The royal dominion over both the Delta and the narrow band of Nile Valley that stretched southward from it was similarly stressed in two of the four regnal names that kings utilized in the First Dynasty: the Nsw-bity throne name and the Two Ladies name. The first of these combined the words for king associated with each of the two crowns, and the second referenced the protective goddesses Nekhbet of El-Kab and Wadjet of Buto, each of whom was also identified with the crown of her region and believed to infuse it with her spirit. Due to the divine nature of these crowns - goddesses in their own right-they typically dwelt in the two most sacred royal ancestral shrines in Egypt, namely the Perwer of Hierakonpolis and the Per-neser of Buto (Frankfort 1978:95-97, 131). These shrines, although quite likely remodeled numerous times over the ages in brick and stone, continued to function as the twin hearts of the cult of kingship throughout Egyptian history and were represented in art and writing as reed shrines of the general type perhaps best typified by the predynastic temple HK29, excavated at Hierakonpolis (HK29-Adams 1999:373).

In royal ideology, then, if there were two crowns, it was important that they be melded into the single crown that sat upon the forehead of the king and infused him with the Two Powers. Likewise, from the First Dynasty onward the existence of the Two very different Lands was trumpeted, but primarily in order to enhance the luster of the royal act of unifying them. Indeed, the first duty of a newly crowned king was to ritually re-enact this foundational event. The First Dynasty annals tersely summarize the cardinal performative events of the coronation: "the appearance of the King of Upper Egypt and Lower Egypt; the union of the Two Lands ( $s m 3 \mathrm{sm}^{\complement} t 3-$ $m h w$ ); the procession around the wall ( $p h r$ h 3 inb)" (e.g., Wilkinson 2000:PS r.V.8; PS v.I.2; CF1 r.III.3). In the act of physically traversing the extent of the white walls of his capital city, the new king symbolically and publicly laid claim—as his ancestors had before him—-to everything that existed within the country's borders. 
The act of investiture that took place in the dual shrines of kingship served a similar purpose, for the regalia received was both sacred and infused with symbolism, much of it related to the king's unique position as the sole unifying symbol of his country. In the Pyramid Texts, for example, in an otherworldly enactment of his coronation, the king asks to receive the shepherd's crook, which functioned to materialize the word "ruler" ( $h k 3)$ and to evoke the metaphor of the king as the caretaker of humanity (envisioned as the noble cattle of the god). The king explicitly asks to receive this crook - which was similar in shape assuredly to that carried by Narmer on his palette and also to the crooks of his predecessors buried in tombs U-547 and U-j at Abydos - so that "the head of Lower and Upper Egypt may be bowed” (Faulkner 1969:PT 222 + Dreyer 1998: pl. 36; Dreyer et al. 1996:21).

The king's role as the unifier of his country was not only stressed in his accession and in the regalia that he adopted as king, but it was ritually reaffirmed in the Sed Festival - the festival of the bull's tail — that served to revivify the king after (ideally) thirty years on the throne. This festival may well be depicted already on the Narmer macehead, judging from the king's enveloping garment, the presence of the boundary markers, the palinquin (of a type that in later $\mathrm{Heb}$ Sed celebrations carried members of the royal family), and the Followers of Horus assembled on their standards. The incorporation of the latter two elements in conjunction with the king's tail and the female dancers may similarly suggest a Sed Festival setting for the imagery on the Scorpion macehead, although this is perhaps too bold a statement as royal ritual is not well understood for this early period. Finally, there is the third massive macehead discovered at Hierakonpolis in the Main Deposit, which depicts a king (probably Narmer or Scorpion) clad in Sed Festival robes, seated under a canopy, and wearing the crown of Lower Egypt (Quibell 1900: pl. 26A). For Early Dynastic kings, too, this ceremony appears from statuary, annals, and other inscriptions to have preoccupied much of their (often anticipatory) attention, as it would for pharaohs ever after (Jiménez Serrano 2002:42-78). It comes then as little surprise that Egypt's first elaborate stone masonry complex, commissioned by a Third Dynasty king named Netjerikhet (lit. The-Divine-One-of-the-Corporationof-Gods), was largely devoted to enabling this king's spirit to celebrate millions upon millions of Sed Festivals.

As essentially a re-enactment of the king's own coronation — and by the same token a commemoration of the original unification of Egypt-Sed 
Festivals essentially elaborated upon the script laid out for a coronation in the royal annals. On the Days of the White Crown and the Days of the Red Crown, the king made his appearance as a Nesu and as a Bity. He ran a race encircling Egypt's symbolic boundary stones (which perhaps evoked in their shape the crenulations of the white walls of Memphis), and by the Third Dynasty at least he did this clutching the deeds to the country as a whole that had been bestowed upon him by the gods. In the course of the ceremony the king visited reed-built representations of the most important sanctuaries of the south and north, including the Per-wer and the Per-neser. He received again the most important symbols of office, and he processed in the company of the Followers of Horus. The intentional and ever increasing archaism of the rites and of their architectural setting was a key feature of the Sed Festival and one boasted about by the officials of Amenhotep III, who had intensively researched these rites in dusty archives (see generally Uphill 1965; Hornung and Staehelin 1974).

If the symbolism inherent in the coronation and the Sed Festival emphasized the king's role as the only personage capable of uniting the Two Lands, the very act of holding these ceremonies demonstrated this point. For these two central festivals of kingship, all the leading figures of the terrestrial and celestial realms came together to pay their respects to the king, to give him gifts, and to receive gifts in return. As the accumulator and the disburser of his country's wealth in these ceremonies and more mundanely in annual practice, the king thus served as the focal point of an extremely impressive administrative apparatus.

\section{THE MESSAGE: THE KING IS THE HEAD OF THE ADMINISTRATION AND THE BESTOWER OF BOUNTY}

A thriving bureaucracy that oversees the accumulation and distribution of surplus is a hallmark of state societies, and its presence appears to be indicated obliquely in the monuments of the earliest kings. The Scorpion macehead, for instance, depicts the king perhaps symbolically "cutting the ribbon" in the context of an agricultural project, presumably one intended to increase future food stores. Whether the king is depicted opening up a new irrigation canal or hacking up earth in preparation for planting is unclear, but the anticipated results of his efforts are not. Facing him, behind the man who proffers his basket to catch the king's earth, is a distinctively 
dressed official holding what looks to be a stylized sheaf of grain. This same official — variously labeled $\underline{t}$ and $\underline{t} t$ and often thought to be the forerunner of the $t 3 t y$ vizier-likewise appears among the king's entourage on Narmer's macehead and palette. Significantly, when this official holds the grain on the Scorpion macehead and when he strides out to view the remains of the massacre on the Narmer Palette, he carries with him a scribal kit.

Writing at the dawn of the state was a very new and seemingly tightly monopolized technology. Excavations in cemetery $U$ at Abydos, and especially at the royal grave $\mathrm{U}-\mathrm{j}$, suggest that the first systematic employment of symbols to represent sounds and convey complex concepts occurred at the time that Upper Egypt was first unified and, thus, that unprecedented quantities of goods and information flowed toward the royal center. Like the use of cylinder seals to mark property, writing was almost certainly an administrative tool imported as a concept from Mesopotamia along with all manner of other precious commodities and exotic imagery (such as the snakey-necked felines on Narmer's Palette). Insofar as it is possible to tell from the many inscriptions recovered from $U-j$, scribes initially employed this technology predominantly to identify the provenience of goods destined to be property of the state (at least insofar as the state was embodied in the person of its dead king). Indeed, this situation seems to have persisted throughout the Early Dynastic Period, judging from the fact that such an overwhelming percentage of contemporary inscriptional evidence comes from the excavations of the royal tombs at Abydos and from the fabulously opulent tombs of the kings' intimates at Saqqara.

The position of the king as the focal point for accumulated surplus, whether agricultural or in the form of human and animal chattel, is brought out in the two maceheads, and it is thus perhaps to be expected that the officials appearing in the Early Dynastic inscriptional repertoire are predominantly those whose duties included the oversight of various royal estates and the collection and storage of resources more generally (Wilkinson 1999:111-33). Indeed, the internal colonization of the Delta with new revenue-producing domains, estates, and even whole towns began at this time full force, continued throughout pharaonic history, and ratcheted up in intensity yet again once Egypt fell under the rule of foreign powers.

The primary method employed by Egypt's first kings to assess and presumably partially requisition the wealth of their new subjects was a biennial tour of the country known in the annals as the Following of Horus, 
perhaps in reference to the four standards that accompanied the king or else simply to the spectacle created by the sight of a royal entourage on the move (perhaps best envisioned by the boat processions depicted in the Painted Tomb at Hierakonpolis, on the Turin Linen, on D-ware pots, on ivory knife handles, and in countless petroglyphs). This waterborne royal progress likely served many purposes, as it has for rulers throughout the world since states began. By touring his country, the monarch was able to make his (undoubtedly resplendent) presence known throughout his realm and to visually enforce the ideology that placed him above all other mortals and in the company of the gods (in the person of their standards). During his progress, the armed contingent of his entourage reminded his regional officials of who was in charge, and the king was simultaneously afforded the opportunity to inspect such men with an eye toward determining their loyalty and potential powerbase. On analogy to later royal travels, the tour undoubtedly also presented the king with an opportunity to pay his respects to the local deities in their temples and perhaps to arbitrate pressing legal matters (Baines 2006:271, 290; Breasted 1988b:91-92; Gardiner 1953:16; Kuhrt 1995:633).

More cynically, however, royal progresses traditionally offer an opportunity for the court to absorb for itself a substantial portion of local revenues in elaborate ceremonial contexts (by virtue of attending feasts and receiving "gifts") and to assess firsthand (in conjunction with knowledge gained from the Nile flood records) realistic expectations for future income. In the Early Dynastic Period, the Following of Horus often explicitly co-occurred with a census $(t n w t)$, and the progress likely should be equated as well with the biennial cattle-count that eventually replaced it and with periodic inventories of specific sources of wealth such as people, fields, livestock, and minerals (e.g., Wilkinson 2000:PS r.III.4; PS r.V.3, 5; CF1 vII.1) that took place at a period when Horus no longer accompanied his tax collectors.

Presumably because showing the flag was no longer deemed necessary once kingship was an unquestioned norm and the country possessed a competent bureaucratic infrastructure, the Following of Horus ceased to be a regular practice by the advent of the Old Kingdom. The cessation may also have been, however, a bow to public opinion, as preparations to receive the king (above and beyond preparations to accumulate the expected taxes) could be burdensome. Under British rule the royal progresses of the Nyoro king in Uganda and Zaire were "frowned upon by the European district 
officials, who held that the Mukama used them as a means of economizing on his palace expenses. They were also growing increasingly unpopular with the people, who were required to contribute labor and foodstuffs to support them, and saw little or no return for their efforts, but they were important traditionally, both in enabling the Mukama to keep an eye on the activities of his chiefs of all ranks in their areas, and also in keeping him in touch with trends in public opinion throughout the country" (Beattie 1971:138). Given the fact that the Early Dynastic royal progress coincided with the original attempts of these kings to naturalize their rule and assert military, economic, and ideological control over their new subjects, it is of interest that the only other time when such royal progresses reappear in Egyptian history is in the reign of Thutmose III, precisely when this king was attempting to solidify and to systematize his control over a newly won and very unruly northern empire.

The amount of revenue garnered from nationwide taxation, from longdistance trade, and from battle (as hinted at by the undoubtedly exaggerated totals of cattle and livestock enumerated on the Narmer macehead) would have been staggering. Certainly, the vast quantities of wealth interred with the First Dynasty kings and with their closest companions buried in the mastabas at Saqqara provide one window onto its expenditure, and no doubt the maintenance of a sumptuous court in a newly created capital city likewise dented the coffers. Much that was accumulated, however, was likely redistributed to gods and priests, to nobles (in the form of boons that the king gave and in reward ceremonies), to workers on state projects and in state workshops, and to state functionaries of all sorts-including those in charge of recording such disbursements! (Compare Sallaberger, this volume, on Mesopotamian kings as the distributors of largesse.) Finally, lavish royal events such as coronations or Sed Festivals were well known for the distribution of the bounty that had been collected, as inscriptions and archaeological evidence at sites such as Malkata attest (Frankfort 1978:130, 132; Hayes 1951:31-40, 82-104, 156-83, 231-42; Hope 1977).

Whether the state's supply was intended also for crisis management, as in times of disastrous floods, is not known. Food relief, the construction of canals (such as might be represented on the Scorpion macehead), and other methods of agricultural intensification undoubtedly bolstered the legitimacy of regional leaders in the First Intermediate Period, and might be speculated to have done so as well at the dawn of the state, as evidence sug- 
gests that floods around this period were particularly unstable (Bell 1970). If the distribution of food to the hungry was indeed an important component of the king's mandate to rule, however, it is remarkable how little this message seems to have been promoted by the court, both in these early monuments and forever after. When royal largess is depicted in state-commissioned artwork, its subject is most often the king offering to the gods or showering golden baubles upon deserving nobles, rather than sharing royal larders with individuals in need. Clearly, then, the pharaoh did not promote himself primarily as man of and for the people, rather he more commonly boasted of his position as a man of and for the gods.

\section{CONCLUSION}

The messages that Scorpion and Narmer composed and communicated to the gods (and to those mortals privileged enough to enter Hierakonpolis' holiest temple) were largely the same ideological tenets that pharaohs promoted in religious and secular contexts for the following three millennia: the king was no ordinary mortal; he possessed access to the world of the gods and successfully solicited their blessings. The king used both force and an able administration to maintain order in his realm, and in his person he alone unified the dangerously disparate parts of his country. The sociologist Michael Mann (1986) has subdivided ultimate power into four potentially discrete spheres: ideological, military, economic, and political. Narmer and Scorpion, already prior to the First Dynasty, had usurped all of these and enfolded them into their own role as king.

Throughout the eons following the reigns of Scorpion and Narmer there were many variations upon these essential themes. The gods that gave the king their blessing (or even engendered him) differed such that at different periods or in different contexts the sun god or the god of one or another capital cities or anthropomorphized concepts might receive the most credit. Some kings stressed their own status as a divinity on earth, while others laid more emphasis upon their role as humanity's intercessor with the gods. All kings took credit for military victories, but some kings trumpeted them more and even accompanied their armies on the day of battle. The amount of resources funneled directly into the royal coffers and spending priorities also changed with administrations, as did the degree to which it was the king who made decisions as opposed to his councilors. For all of 
the rulers who adopted the red and white crowns and endeavored to rule Egypt, however, the legacy left to them had been articulated already on the outsized maces and palettes of two primordial rulers and in the ceremonies and performances they staged in order to publicize the foundational tenets of their new ideology.

\section{NOTE}

1.1 This cache, discovered in 2007, is as yet published only online. See http://www. archaeology.org/interactive/hierakonpolis/ field07/6.html, accessed May 27, 2008.

\section{REFERENCES}

Adams, B. 1995. Ancient Nekhen. Garstang in the City of Hierakonpolis. Surrey: SIA Publishing.

- 1999. Hierakonpolis. In Encyclopedia of the Archaeology of Ancient Egypt, ed. K. Bard, pp. 371-74. New York: Routledge.

Baer, K. 1960. Rank and Title in the Old Kingdom: The Structure of the Egyptian Administration in the Fifth and Sixth Dynasties. Chicago: University of Chicago Press.

Baines, J. 1994. On the Status and Purposes of Ancient Egyptian Art. CAJ 4 (1): 67-94.

1995a. Kingship, Definition of Culture, and Legitimation. In Ancient Egyptian Kingship, ed. D. O’Connor and D.P. Silverman, pp. 30-47. PdÄ 9. New York: Brill.

- 1995b. Origins of Egyptian Kingship. In Ancient Egyptian Kingship, ed. D. O’Connor and D.P. Silverman, pp. 95-156. PdÄ 9. New York: Brill.

- 2006. Public Ceremonial Performance in Ancient Egypt: Exclusion and Integration. In Archaeology of Performance. Theaters of Power, Community, and Politics, ed. T. Inomata and L.S. Coben, pp. 261-302. New York: AltaMira Press. Beattie, J. 1971. The Nyoro State. London: Oxford University Press.

Bell, B. 1970. The Oldest Records of the Nile Floods. Geographical Journal 136:569-73.

Blackman, A.M. 1915. The Pharaoh's Placenta and the Moon-God Khons. JEA 3:235-49.

Braun, E. 2002. Egypt's First Sojourn in Canaan. In Egypt and the Levant. Interrelations from the 4th through the Early 3rd Millennium B.C.E., ed. E.C.M. van den Brink and T.E. Levy, pp. 173-89. New York: Leicester University Press. 
Breasted, J.H. 1988a. Ancient Records of Egypt I. London: Histories \& Mysteries of Man, Ltd. Reprint.

1988b. Ancient Records of Egypt II. London: Histories \& Mysteries of Man, Ltd. Reprint.

Brunner, H. 1982. Menes. LÄ IV, ed. W. Helck et al., pp. 46-48. Weisbaden: Harrassowitz.

Carter, H. 1972. The Tomb of Tutakhamen. New York: E.P. Dutton.

Crubezy, É., and B. Midant-Reynes. 2000. Les sacrifices humains à l'époque prédynastique: L'apport de la nécropole d'Adaïma. Archéo-Nil 10:21-40.

Dreyer, G. 1998. Umm el-Qaab I. Das prädynastische Königsgrab U-j und seine frühen Schriftzeugnisse. Mainz: Philipp von Zabern.

Dreyer, G., E.-M. Engel, U. Hartung, T. Hikade, E. C. Köhler, and F. Pumpenmeier. 1996. Umm el-Qaab. Nachuntersuchungen im frühzeitlichen Königsfriedhof $7 / 8$ Vorbericht. MDAIK 52:11-81.

Dreyer, G, U. Hartung, T. Hikade, E.C. Köhler, V. Müller, and F. Pumpenmeier. 1998. Umm el-Qaab. Nachuntersuchungen im frühzeitlichen Königsfriedhof. 9/10 Vorbericht. MDAIK 54:77-167.

DuQuesne, T. 2005. The Jackal Divinities of Egypt I: From the Archaic Period to Dynasty X. Oxfordshire Communications in Egyptology VI. London: Darengo Publications.

Erman, A., and H. Grapow. 1929. Wörterbuch der Ägyptischen Sprache III. Leipzig: J.C. Hinrichs.

Faulkner, R.O. 1969. The Ancient Egyptian Pyramid Texts. Warminster: Aris \& Phillips.

Feeley-Harnik, G. 1985. Issues in Divine Kingship. Annual Review of Anthropology 14:273-313.

Frankfort, H. 1978. Kingship and the Gods. A Study of Ancient Near Eastern Religion as the Integration of Society and Nature. Chicago: University of Chicago Press.

Friedman, R.F. 1996. The Ceremonial Center at Hierakonpoils HK29A. In Aspects of Early Egypt, ed. J. Spencer, pp. 16-35. London: British Museum Press.

2004. Elephants at Hierakonpolis. In Egypt at Its Origins. Studies in Memory of Barbara Adams, ed. S. Hendrickx, R.F. Friedman, K.M. Cialowicz, and M. Chlodnicki, pp. 131-68. Leuven: Peeters.

Gardiner, A.H. 1953. The Coronation of King Haremhab. JEA 39:13-31.

Habachi, L. 1963. King Nebhepetre Mentuhotep: His Monuments, Place in History, Deification and Unusual Representation in the Form of Gods. MDAIK 
19:16-52.

-1969. Features of the Deification of Ramesses II. Glückstadt: J.J. Augustin.

Hayes, W.C. 1951. Inscriptions from the Palace of Amenhotep III. JNES 10:3556, 82-104, 156-83, 231-42.

Hope, C. 1977. Jar Sealings and Amphorae of the 18th Dynasty: A Technological Study. Warminster: Aris \& Phillips.

Hornung, E. 1982. Conceptions of God in Ancient Egypt. The One and the Many, trans. J. Baines. Ithaca: Cornell University Press.

Hornung, E., and E. Staehelin. 1974. Studien zum Sedfest. Basel: Edition de Belles-Lettres.

- 1987. Studies on the Middle Kingdom. Budapest: Chaire de l'Égyptologie.

Jiménez Serrano, A. 2002. Royal Festivals in the Late Predynastic Period and the First Dynasty. Oxford: BAR International.

Kaiser, W. 1959. Einige Bemerkungen zur agyptischen Fruhzeit I: Zu den šmsw-hrr. ZÄS 84:119-32.

Kaiser, W., and G. Dreyer. 1982. Umm el-Qaab. Nachuntersuchungen im frühzeitlishen Königsfriedhof. 2. Vorbericht. MDAIK 38:211-69.

Kaplony, P. 2002. The Bet Yerah Jar Inscription and the Annals of King DewenDewen as "King Narmer Redivivus." In Egypt and the Levant. Interrelations from the 4th through the Early 3rd Millennium B.C.E., ed. E.C.M. van den Brink and T.E. Levy, pp. 464-86. New York: Leicester University Press.

Keita, S.O.Y., and A.J. Boyce. 2006. Variation in Porotic Hyperostosis in the Royal Cemetery Complex at Abydos, Upper Egypt, a Social Interpretation. Antiquity 80, no. 307:64-73.

Kemp, B. 1991. Ancient Egypt: Anatomy of a Civilization. London: Routledge.

- 2000. The Colossi from the Early Shrine at Coptos in Egypt. CAJ 10:211-42.

Köhler, E.C. 2004. On the Origins of Memphis-The New Excavations in the Early Dynastic Necropolis at Helwan. In Egypt at Its Origins. Studies in Memory of Barbara Adams, ed. S. Hendrickx, R.F. Friedman, K.M. Cialowicz, and M. Chlodnicki, pp. 295-315. Leuven: Peeters.

Kuhrt, A. 1995. The Ancient Near East c. 3000-330 BC, Volume Two. New York: Routledge.

Lichtheim, M. 1975. Ancient Egyptian Literature I: The Old and Middle Kingdoms. Berkeley: University of California Press.

Mann, M. 1986. The Sources of Social Power: A History of Power from the Beginning to $A D$ 1760, Vol. I. Cambridge: Cambridge University Press. 
Morris, E. 2007. Sacrifice for the State: Royal Funerals and the Rites at Macramallah's Rectangle. In Performing Death. Social Analyses of Ancient Funerary Traditions in the Mediterranean, ed. Nicola Laneri, pp. 15-37. Oriental Institute Seminars 3. Chicago: Oriental Institute.

Parkinson, R. 1997. The Tale of Sinuhe and Other Ancient Egyptian Poems 19401640 BC. New York: Oxford University Press.

Petrie, W.M.F. 1989[1900]. The Royal Tombs of the First Dynasty, Part I. London: Egypt Exploration Fund (reprint by Histories \& Mysteries of Land).

Posener, G. 1965. Le nom de l'ensigne appelée “Khons.” RdE 17:193-95.

Quibell, J.E. 1900. Hierakonpolis I. London: B. Quaritch.

Quibell, J.E., and F.W. Green. 1902. Hierakonpolis II. London: B. Quaritch.

Sethe, K. 1933. Urkunden des Alten Reichs I. Leipzig: J.C. Hinrichs'sche Buchhandlung.

Silverman, D.P. 1995. The Nature of Egyptian Kingship. In Ancient Egyptian Kingship, ed. D. O’Connor and D.P. Silverman, pp. 49-87. PdÄ 9. New York: E.J. Brill.

Spencer, A.J. 1993. Early Egypt: The Rise of Civilisation in the Nile Valley. Norman: University of Oklahoma Press.

Strudwick, N.C. 2005. Texts from the Pyramid Age. Writings from the Ancient World 16. Atlanta: Society of Biblical Literature.

Te Velde, H. 1967. Seth, God of Confusion: A Study of His Role in Egyptian Myth and Religion. PdÄ 6. Leiden: Brill.

- 2001. Seth. In Oxford Encyclopedia of Ancient Egypt III, ed. D.B. Redford, pp. 269-71. New York: Oxford University Press.

Uphill, E. 1965. The Egyptian Sed-Festival Rites. JNES 24:365-83.

Warman, S. 2004. Predynastic Egyptian Bovid Burial in the Elite Cemetery at Hierakonpolis. In Behavior Behind Bones. The Zooarchaeology of Ritual, Religion, Status and Identity, ed. S.J. O’Day et al., pp. 34-40. Oxford: Oxbow Books.

Wengrow, D. 2006. The Archaeology of Early Egypt: Social Transformations in North-East Africa, 10,000-2,650 B.C. Cambridge: Cambridge University Press. Wildung, D. 1977. Egyptian Saints: Deification in Pharaonic Egypt. New York: New York University Press.

Wilkinson, T. 1999. Early Dynastic Egypt. New York: Routledge.

- 2000. Royal Annals of Ancient Egypt. The Palermo Stone and Its Associated Fragments. New York: Kegan Paul International.

Williams, B.B. 1988. Narmer and the Coptos Colossi. JARCE 25:35-59. 